\title{
DINAMIKA KOMUNIKASI POLITIK DALAM PEMILIHAN UMUM
}

\author{
Eko Harry Susanto \\ Fakultas Ilmu komunikasi Universitas Tarumanagara Jakarta
}

\begin{abstract}
ABSTRAK
Kebebasan dalam berkomunikasi yang mewarnai kehidupan politik, berdampak terhadap tuntutan demokratisasi bernegara yang faktual melalui pemilihan umum yang berkeadilan dan menghasilkan anggota legislatif yang berpihak kepada rakyat. Penelitian tentang dinamika komunikasi politik dan Pemilihan Umum bertujuan untuk memberi gambaran tentang dinamika komunikasi politik dalam rangka menghadapi pemilihan umum. Temuan penelitian mencakup, keberadaan para komunikator politik yang terdiri dari elite parpol dan calon anggota legislatif, partisipasi masyarakat dalam menggunakan hak suara, dan kualitas anggota legislatif hasil pemilihan umum. Ketiga temuan tersebut merupakan faktor mendasar pendukung keberhasilan pelaksanaan pemilihan umum yang menghasilkan anggota legislatif berkualitas. Penelitian ini menggunakan metodologi kualitatif yang dititikberatkan pada penelusuran data yang berkaitan dengan pemilu legislatif.
\end{abstract}

Kata-kata kunci: Komunikasi politik, partisipasi masyarakat, kualitas anggota legislatif

\section{POLITICAL COMMUNICATION DYNAMICS IN ELECTION}

\begin{abstract}
The freedom of communication which characterize political life, has impacts on the demands of the factual state of democratization through fair general elections and produces legislators who sided with the people. This research on the dynamics of political communication and General Election, aims to give an overview of the dynamics in political communication confronting the general election. Finding includes the existence of political communicators consisting of elite political parties and legislative candidates, people participation in the use of voting rights, and quality of elected legislators through general election. Those three finding are a fundamental factor to support the successful implementation of a general election which generates a quality legislator. This study uses a qualitative methodology focused on data related to the legislative general elections.
\end{abstract}

Keywords: Political communication, public participation, quality of legislative members

Korespondensi: Dr. Eko Harry Susanto, M.Si. Fakultas Ilmu komunikasi Universitas Tarumanagara Jakarta, Jln. Letjen. S. Parman No. 1, Grogol, Jakarta Barat 11440.Email: ekohs@centrin.net.id, ekoharry@yahoo.com 


\section{PENDAHULUAN}

Memasuki kebebasan berkomunikasi pasca reformasi politik di Indonesia, pembicaraan politik di forum terbuka yang mengkritisi kebijakan pemerintah menjadi hal yang biasa. Padahal, sebelumnya tidak mudah mengungkapkan kritik terhadap pelayanan publik di Indonesia. Terlebih lagi jika kritik dan ketidaksepakatan menyangkut pusat - pusat kekuasaan, yang mengendalikan roda pemerintahan, jelas sebagai tindakan yang sulit ditemukan.

Bahkan sebatas bernostalgia terhadap sisi positif masa pemerintahan sebelumnyapun, sulit diungkapkan di ruang - ruang publik, akibat kontrol ketat terhadap arus informasi lateral maupun vertikal dari pemerintahan sebelum reformasi politik. Terjadinya perubahan sistem politik di Indonesia sejak tahun 1998, jelas membawa dampak kompleks dalam kebebasan mencari, menggunakan dan menyampaikan pendapat kepada rakyat. Karena satu sisi, menerima dengan gegap gempita kebebasan berkomunikasi, di pihak lainnya, justru merasa terganggu dan memposisikan demokrasi berkomunikasi merupakan biang keladi dari berbagai masalah yang dihadapi bangsa dan negara.

Tentu saja dapat dimaklumi, mengingat pola komunikasi dalam pemberitaan, penyiaran dan pembicaraan publik, yang diunggulkan adalah demi stabilitas nasional. Sebuah jargon komunikasi politik populer pada massanya, yang menghasilkan komunikasi linier datar dalam bingkai keserasian, keselarasan dan keseimbangan. Dalam nuansa tanpa gejolak dan keseragaman informasi satu arah tanpa interaksi egaliter, maka ruang - ruang publik diisi oleh komunikasi politik sebagai epigon retorika kekuasaan negara, yang cenderung mengedepankan keberhasilan dibandingkan ketidakmampuan mengemban sejumlah tugas pembangunan untuk seluruh rakyat, tanpa diferensiasi sosial, ekonomi dan politik.

Karena itu, ketika Indonesia memasuki era kemerdekaan berekspresi sangat beralasan jika selalu muncul pro dan kontra terhadap etika komunikasi atau pembicaraan di ruang publik. Namun yang harus dijunjung tinggi bersama tentang kebebasan berpendapat adalah landasan hukum kebebasan berkomunikasi. Menurut Undang - Undang Dasar 1945, pasal 28F, menyebutkan: "Setiap orang berhak un- tuk berkomunikasi dan memperoleh informasi untuk mengembangkan pribadi dan lingkungan sosialnya, serta berhak untuk mencari, meperoleh, memiliki, menyimpan, mengolah, dan menyampaikan informasi dengan menggunakan segala jenis saluran yang tersedia".

Berpijak kepada ketentuan ini, maka kebebasan berkomunikasi merupakan hak masyarakat. Menurut Bill Kovach dan Tom Rosenthiel (dalam Haryanto, 2010: 7), " hak atas informasi merupakan hak dasar yang melekat pada manusia, atau sebagai kesadaran manusia untuk mengetahui hal - hal diluar dirinya". Dalam penyelenggaraan pemerintah, hak berkomunikasi seringkali dikaitkan dengan komunikasi politik atau penyampaian pesan - pesan kepada khalayak atau rakyat yang didalamnya mengandung kebijakan kekuasaan negara.

Secara umum, komunikasi politik lazim dikaitkan dengan pembicaraan politik atau penyampaian pesan politik verbal maupun non verbal yang dapat mempengaruhi rakyat maupun pemerintah dalam suatu sistem politik. Atau secara sederhana dapat disebutkan bahwa komunikasi politik adalah penyampaian pesan yang bermuatan politik dari suatu sumber kepada penerima untuk menciptakan pemahaman makna bersama.

Mengingat komunikasi melekat pada setiap orang sebagaimana, menurut Watzlawik (dalam Bower dan Bradac, 1982: 3), "manusia adalah mahluk yang tidak bisa tidak berkomunikasi", maka setiap tingkah laku manusia, termasuk pada saat diam, dan tidak merespon pesan politik dari suatu sumber, tetap saja menimbulkan makna yang berhubungan dengan nuansa politik.

Dalam hubungannya dengan kehidupan berbangsa dan bernegara, Bambang Setiawan (1990: 407) berpendapat, "komunikasi politik adalah proses penyampaian pendapat, sikap dan tingkah laku orang - orang, lembaga - lembaga atau kekuatan - kekuatan politik dalam rangka mempengaruhi pengambilan keputusan politik, sedangkan yang dimaksud dengan politik tidak lain adalah kehidupan bernegara". Secara fleksibel, "komunikasi politik merupakan komunikasi yang mengacu pada kegiatan politik" (Nimmo, 2007: 8). Dengan demikian semua kegiatan bernuansa politis, yang dilakukan oleh pemerintah, atau kekuasaan negara beserta institusi pendukung maupun yang dilakukan 
rakyat pada umumnya, merupakan bentuk komunikasi politik

Berpijak kepada uraian tersebut diatas, masalah dalam penelitian ini adalah bagaimana para aktivis mampu menjadi komunikator politik, bagaimana cara mengajak khalayak supaya berpartisipasi dalam pemilihan umum dan profil yang seperti apa harapan terpilihnya anggota legislatif.

Tujuan penelitian ini untuk menggambarkan dan menganalisis perilaku para komunikator dalam dinamika politik nasional dan pemilihan umum legislatif, bagaimana para komunikator politik mempengaruhi partisipasi masyarakat, dan apa kriteria wakil rakyat yang berpihak kepada rakyat. Sedangkan manfaat penelitian ini, diharapkan memberikan sumbangan pemikiran apa yang seharusnya dilakukan oleh para aktivis politik praktis, wakil rakyat ataupun anggota legislatif dan pihak - pihak yang bertanggung jawab terhadap pelaksanaan pemilihan umum yang demokratis dan beradab. Sedangkan tinjauan pustaka memfokuskan kepada konsepsi mendasar tentang komunikasi politik, strategi persuasi, pembiayaan iklan kampanye politik, sistem politik dan demokratisasi bernegara dari sudut kebebasan berkomunikasi.

\section{METODE PENELITIAN}

Metodologi yang digunakan dalam penelitian ini bersifat kualitatif. Penelitian kualitatif dimaksudkan untuk memahami arti atau mencari makna dari peristiwa dan kaitan-kaitannya dengan orang-orang biasa dalam situasi tertentu (Moleong, 2005: 9). Esensinya, penelitian kualitatif bertujuan mengungkap makna terhadap fenomena perilaku kehidupan manusia, baik dalam kapasitas sebagai individu, kelompok maupun masyarakat luas, yang berkaitan komunikasi politik dan partisipasi dalam pemilihan umum.

Upaya mengeksplorasi suatu peristiwa, kejadian dan simbol - simbol dalam penelitian ini, menitikberatkan pada penelusuran dokumen dan informasi seputar dinamika politik nasional yang berhubungan dengan pemilihan umum anggota legislatif tahun 2014. Dengan mencermati gejala - gejala ketidakpercayaan masyarakat terhadap kemungkinan membengkaknya golongan putih (golput) atau mereka yang terdaftar sebagai pemilih tetapi tidak menggunakan haknya, karena berbagai alasan yang bersifat individual maupun ketidakpercayaan bahwa anggota legislatif di pusat maupun daerah yang dihasilkan dalam pemilihan umum tidak berkualitas dan tidak berpihak kepada rakyat.

\section{HASIL DAN PEMBAHASAN}

Komunikasi politik dalam bentuk retorika, pidato dan penyampaian pesan - pesan politik seperti halnya kampanye di ruang publik maupun dalam kelompok kecil yang terjadi di Indonesia, dapat diamati melalui berbagai aspek yang melekat dalam komunikasi politik. Banyak sekali pidato - pidato dalam bingkai komunikasi politik dari para elite di Indonesia yang memiliki kaitan dengan pemilihan umum tahun 2014. Sebagaimana dalam Harian Republika tentang Surya Paloh yang melakukan komunikasi politik dengan Megawati tentang Pemilihan Umum 2014 (Republika: 2103).

Dalam komunikasi politik, sesungguhnya setiap aspek memiliki peran tersendiri, walaupun tetap memiliki hubungan secara langsung ataupun tidak langsung dalam aplikasinya. Lima komponen dalam komunikasi politik tersebut menyangkut (1) komunikator politik, (2) pesan politik (3) media yang digunakan dalam komunikasi politik, (4) khalayak komunikasi politik, dan (5) Akibat yang ditimbulkan dari komunikasi dalam politik. (Nimmo, 2007: 114).

Komunikator politik adalah orang yang mempunyai kemampuan dalam menjalankan komunikasi politik. Melekat didalamnya adalah posisi strategis sebagai "politikus", yang menjaga kredibilitas dan branding individual, atau institusi dimana komunikator bernaung. Sebagai politikus, bisa berada di dalam atau di luar jabatan pemerintah, namun harus tetap menjaga integritas nasional. Sejalan dengan kontestasi politik nasional, maka muncul pula "komunikator politik profesional" yang memanfaatkan saluran media mainstream maupun media alternatif untuk mempengaruhi massa. Para komunikator politik bisa saja berasal dari "aktivis" kelompok kepentingan (interest group) tertentu dan pemuka pendapat (opinion leader) yang memiliki posisi khusus di masyarakat. Hakikatnya politisi, komunikator profesional dan aktivis sebagai komunikator politik, harus memiliki kemampuan dalam melakukan ko- 
munikasi politik sehingga berkesempatan dan memiliki kapasitas sebagai pemimpin yang mampu mengorganisasikan pesan kepada khlayak dengan baik.

Pesan politik dihubungkan dengan lambang atau simbol, bahasa dan opini publik. Ketiga faktor itu selalu melekat dalam informasi politik yang disebarkan oleh komunikator kepada masyarakat untuk mencapai tujuan politik. Simbol juga dapat mengkomunikasikan konsep, gagasan umum, bentuk pemahaman makna yang sederhana, dan mudah dipahami dalam hubungan antara komunikator politik dengan khalayak. Setidaknya berdasarkan penelusuran data online melalui google, terdapat sekitar 1.090.000 tulisan yang mengandung kata komunikasi politik elite dalam pemilu 2014 (Kominfo, 2012)

Dalam penyampaian pesan politik, digunakan "strategi persuasi" sebagai teknik penyampaian pesan melalui kampanye, propaganda dan penggalangan opini publik. Menurut Dan Nimmo (2007: 125), strategi persuasi merupakan suatu alat yang dipergunakan oleh kelompok terorganisasi, untuk menjangkau individu - individu yang secara psikologis dimanipulasi dan digabungkan ke dalam organisasi.

Penyebaran pesan politik dilakukan juga melalui "iklan politik" yang diarahkan kepada kelompok massa yang heterogen dan "retorika" sebagai bentuk komunikasi transaksional untuk memperoleh manfaat timbal balik. Otto Klepper (1980: 21) menadaskan, bahwa tidak ada alat komunikasi untuk menyampaikan pesan yang dapat dipahami oleh khalayak, selain periklanan yang dapat mencapai publik seefektif iklan. Sedangkan retorika yang berkaitan dengan komunikasi di depan publik, lebih mengarah kepada retorika deliberatif yaitu, jenis retorika yang menentukan tindakan yang harus diambil oleh khalayak dengan mempengaruhi atau memaparkan aspek yang menarik perhatian. (West dan Turner, 2008)

Namun strategi persuasi, iklan politik dan retorika tidak semata - mata mampu meraih dukungan massa, karena itu harus menggunakan saluran komunikasi "interpersonal", "saluran organisasi”, misalnya partai politik, kelompok kepentingan dan organisasi massa yang memiliki tujuan spesifik. Saluran lain yang sangat potensial untuk menyebarkan pesan politik melalui komunikasi massa untuk menciptakan makna bersama antara media massa dan khalayaknya. (Baran, 2012: 7). Sejalan dengan itu, Biagi (2005: 7), menyatakan "Komunikasi massa dari satu orang atau sekelompok orang melalui perangkat transmiting (medium) untuk audiens besar atau pasar". Tujuannya untuk menyebarkan program dan ideologi supaya lebih dikenal khalayak. Secara substansial, ideologi adalah pikiran yang terorganisir, yakni nilai, orientasi dan kecenderungan yang saling melengkapi hingga membentuk perspektif - perspektif ide yang diungkapkan melalui komunikasi dengan media teknologi dan komunikasi antar pribadi. (Lull, 1998: 1).

Penggunaan media massa seperti media cetak, media elektronik maupun media-online, untuk menyebarkan pesan politik yang dapat menjangkau sasaran khalayak heterogen dan sangat luas. Mengutip pendapat Bernard Henessy (1990: 24), media massa memang memiliki tanggungjawab untuk selalu memberikan informasi, tayangan dan siaran yang benar, akurat dan jelas. Dengan fungsi itu, media mampu memasok kebutuhan informasi khalayak.

Dalam komunikasi politik, fakta paling realistis untuk dipakai sebagai ukuran keberhasilan penyampaian pesan, adalah meningkatnya jumlah khalayak yang menyepakati apa isi pesan. Lebih tegas lagi adalah bersedia menjadi pengikut dari komunikator politik. Dalam kontestasi politik, harapannya adalah bersedia untuk memberikan suaranya dalam pemilihan umum.

Menambah pengikut dan jumlah khalayak dapat dibentuk melalui opini yang dibentuk oleh komunikator politik. Persoalannya opini publik bisa diterima secara luas oleh masyarakat atau ditolak karena tidak memberikan manfaat berarti bagi khalayaak. Komunikator politik wajib membangun pendapat umum, dengan merumuskan isu yang berhubungan dengan persaingan politik dan kegiatan politik lain yang dinilai bisa meningkatkan kepercayaan publik. Keberhasilan membuat opini publik adalah kunci dari terbentuknya khalayak dalam komunikasi politik, mengingat pendapat umum sangat sensitif terhadap masalah yang menyangkut kepentingan dan dirasakan oleh masyarakat luas.

Jika pengaturan pesan dalam komunikasi politik bisa menyentuh kebutuhan masyarakat secara mendasar dan dilakukan terprogram dan berkesinambungan, maka dampak politik yang 
dihasilkan adalah meningkatnya kredibilitas komunikator politik dengan partai politiknya. Menyampaikan pesan, informasi dan berita politik yang terus menerus dalam program sosialisasi politik yang dilakukan oleh komunikator politik merupakan pembelajaran politik dan partisipasi politik dari masyarakat

Ini bukan pekerjaan mudah, sebab jika kita mencermati, data keterlibatan masyarakat dalam pemungutan suara sebagai perwujudan partisipasi politik yang paling sederhana, semakin menurun sejak pemilihan umum tahun 2004. Golongan Putih (Golput) atau mereka yang tidak memanfaatkan hak pilihnya pada "Pemilu Legislatif" tahun 2004 sebesar 20.579.661 orang atau sekitar 23,24\%. (Suara Pembaruan, 2009).

Dalam Pemilu Legislatif tahun 2009, jumlah golput 49.212.158 (27,77\%). Jumlah ini lebih banyak, dibandingkan dengan perolehan suara Partai Demokrat, sebesar 21.703.137 suara. (Kompas, 10 Mei 2009). Sedangkan Pemilihan Presiden tahun 2004, putaran pertama, jumlah yang tidak menggunakan hak suaranya sekitar 23,47\%. Pada putaran kedua meningkat menjadi $24,95 \%$. Bahkan pada pemilihan Presiden tahun 2009 jumlahnya menjadi $27,77 \%$ atau seki$\operatorname{tar} 49.212 .158$ orang yang tidak menggunakan hak suara (Susanto, 2012: 98).

Padahal pemilu tahun 2009, biaya iklan politik yang dikeluarkan mencapai $\mathrm{Rp} 2,154$ triliun. Naik tajam sekitar 335 persen dibanding Pemilu 2004, dengan total dana iklan politik, di luar iklan pemerintah sekitar Rp 400 miliar. Biaya komunikasi politik untuk mempengaruhi pemilih, melalui iklan politik memang besar. Tanpa melihat biaya tersebut, "siapa" yang mengeluarkan, namun ternyata hanya bisa menarik suara kumulatif 121.504.481 suara sah, dari 176.367.056 pemilih terdaftar.

Mencermati gambaran itu, sosialisasi politik perlu dilakukan secara berkesinambungan demi menarik partisipasi politik masyarakat. Jadi bukan hanya meningkat pada saat menjelang diadakan pemungutan suara. Sebab sosialisasi politik merupakan proses memperkenalkan sistem politik kepada seseorang, dan bagaimana orang tersebut menentukan tanggapan serta reaksinya terhadap gejala - gejala politik (Rush dan Althoff, 1997: 27). Sementara itu, partisipasi politik menurut Budiardjo (2004: 183), merupakan kegiatan sesorang atau sekelompok orang untuk ikut serta secara aktif dalam kehidupan politik, dengan jalan memilih kepala negara dan, secara langsung atau tidak langsung, mempengaruhi kebijakan pemerintah.

Esensinya partisipasi politik masyarakat diperlukan untuk membangun keberadaban bernegara sebagaimana kritik yang dikemukakan Ketua Umum Partai Gerindra Suhardi (2013), bahwa warga negara yang tidak menggunakan hak pilihnya (golput) dalam pemilu. Menurutnya, orang-orang yang melakukan golput juga ikut bertanggung jawab terhadap kehancuran bangsa. Fenomena golput memang selalu ada walaupun ada perbedaan di era Orde Baru dan era Reformasi. Pada masa Orba, ajakan golput adalah sebagai bentuk perlawanan politik, terhadap arogansi pemerintah yang dianggap tidak menjunjung asa demokrasi. Pada era reformasi yang lebih demokratis, pengertian golput adalah bentuk dan fenomena dalam demokrasi. Dari beberapa sisi, sikap golput adalah idealis. (Pikiran Rakyat, 2013).

Prinsip pemilihan umum yang demokratis, harus berpijak kepada pemerintahan dari rakyat oleh rakyat dan untuk rakyat. Dengan demikian pemerintah mendapat kekuasaannya adalah dari mereka yang diperintah. (Stephenson, 2001: 15). Demokratisasi dalam bernegara menuntut penyelenggaraan pemilihan umum yang demokratis. Tidak ada tekanan dari berbagai pihak yang berkepentingan dalam kontestasi politik nasional maupun internasional.

Menurut Urofsky (2001: 2), untuk menjalankan pemerintahan demokratis yang adil dan makmur, terdapat sejumlah prinsip untuk memahami dan mempraktekkan demokrasi secara nyata, antara lain adalah pemerintahan yang berdasarkan pada konstitusi sebagai hasil kesepakatan bersama termasuk para pendiri negara, pemilihan umum yang dilaksanakan secara demokratis bebas dari tekanan pihak manapun yang memiliki kepentingan, peran media yang bebas, independen, dan hak masyarakat untuk mengetahui berbagai hal yang dikerjakan oleh elite dalam kekuasaan negara dan badan- badan publik yang berhubungan langsung maupun tidak langsung dengan rakyat. Selain masalah tersebut, terdapat berbagai aspek lainnya yang secara substantif, berkaitan dengan demokratisasi dalam menjalankan pemerintahan.

Representasi demokrasi dalam pemerintahan adalah pelaksaan pemilihan umum yang bebas, 
untuk menghasilkan pimpinan memerintah berdasarkan konstitusi. James Madison (dalam Stephenson, 2001: 15) menyebutkan, "tujuan dari semua konstitusi adalah, pertma untuk mendapatkan para penguasa, orang - orang yang memiliki kebijakan tertinggi untuk melihat dengan jelas, dan yang paling baik untuk mengejar tujuan bersamaa masyarakat". Jelas disdini bahwa fokus utama dari sebuah konstitusi adalah mencapai tujuan yang bermanfaat untuk rakyat. Karena itu, pemilihan umum dengan beragam regulasi pendukungnya, tetap mengutamakan kepentingan rakyat.

Berdasarkan Undang - Undang Republik Indonesia Nomor. 8 tahun 2012 tentang Pemilihan Umum Anggota Dewan Perwakilan Rakyat, Dewan Perwakilan Daerah, Dan Dewan Perwakilan Rakyat Daerah, "Pemilihan Umum (Pemilu) adalah sarana pelaksanaan kedaulatan rakyat, yang dilaksanakan secara langsung, umum, bebas, rahasia, jujur, dan adil dalam Negara Kesatuan Republik Indonesia berdasarkan Pancasila dan Undang-Undang Dasar Negara Republik Indonesia Tahun 1945.

Dalam pandangan Stephenson (2001: 16), pemilu adalah, "mewujudkan pemerintahan dari rakyat, oleh rakyat dan untuk rakyat". Ditentukan secara damai, memberikan semangat kepada rakyat untuk menggunakan hak suara, akses memberikan hak suara bersifat terbuka, kesetaraan suara- suara sehingga tidak ada suaraa yang dihitung lebih dari yang lain. Hasil pemilu ditentukan melalui aturan sebelumnya, dengan sesedikit mungkin kecurangan dan penipuan dalam pencoblosan dan penghitungan suara.

Dihubungkan dengan paradigma komunikasi politik sebagai upaya penyampaian pesan - pesan politik, pemilu memiliki signifikansi dengan masalah hak masyarakat untuk mengetahui program para kandidat dalam pemilu anggota legislatif. Perwujudan paling nyata dari testimoni ini adalah pelaksanaan kampanye, sosialisasi politik dan beragam kegiatan mengeksplorasi pesan politik kepada rakyat melalui saluran - saluran organisasi, media massa konvensional maupun media alternatif yang memiliki kekuatan dalam menjangkau khalayak yang lebih luas.

Dalam pelaksanaan Pemilu aspek yang paling menonjol adalah masalah kampanye sebagai suatu kegiatan peserta Pemilu untuk meyakinkan para pemilih dengan menawarkan visi, misi, dan program calon anggota legislatif di tingkat pusat maupun daerah dari partai politik maupun calon presiden. Urgensi kampanye dalam pemilu juga tampak dari ketentuan yang terdapat dalam UU No.8/2012. Terdapat 68 pasal yang mengatur tentang kompleksitas pelaksanaan kampanye dalam pemilihan anggota legislatif yang mengatur dari isi kampanye, tempat penyelenggaraan, batas waktu pelaksanaan kampanye dan sejuimlah aturan lain yang berupaya untuk meminimalisir pelanggaran dalam komunikasi politik yang memiliki potensi konflik cukup tinggi.

Sesungguhnya kampanye politik dalam pemilihan calon anggota legislatif sudah dimulai sejak seseorang mendaftarkan diri sebagai kandidat anggota legislatif. Sebab, syarat untuk menjadi anggota legislatif atau Dewan Perwakilan Rakyat (DPR) Republik Indonesia muapun Dewan Perwakilan Rakyat Daerah (DPRD) yang berfokus kepada kepribadian dan berbagai aspek positif lain yang harus dimiliki kandidat anggota legislatif seperti yang dimuat dalam pasal 51 UU No.8/2013. Tentu sangat wajar mengingat anggota DPR/ DPRD adalah orang - orang terpilih yang menjadi wakil rakyat yang memperjuangkan kesejahteraan masyarakat.

Karena itu, calon anggota legislatif sejak dini harus terlibat dalam komunikasi politik dengan rakyat. Bukan pada saat pencalonan saja dalam bingkai instan, tetapi merintis sejak awal untuk memperjuangkan aspirasi rakyat adalah keharusan yang harus dijalankan secara konsisten. Tidak bisa dikesampingkan, sejak reformasi politik, citra anggota legislatif belum sesuai harapan rakyat sebagai konstituen.

Berikut polling Kompas (27 Agustus 2007) yang menunjukkan citra DPR di masyarakat dengan hasil tidak sesuai harapan rakyat:

Tabel 1 Polling Kompas tentang Citra DPR

\begin{tabular}{cccc}
\hline Tahun & Baik & Buruk & $\begin{array}{c}\text { Tidak } \\
\text { tahu }\end{array}$ \\
\hline 2004 & $25 \%$ & $68 \%$ & $7 \%$ \\
\hline 2005 & $29 \%$ & $60 \%$ & $11 \%$ \\
\hline 2006 & $28 \%$ & $65 \%$ & $7 \%$ \\
\hline 2007 & $27 \%$ & $66 \%$ & $7 \%$ \\
\hline
\end{tabular}

Sumber : Harian Kompas, 27 Agustus 2007 
Melihat tabel tersebut, citra anggota DPR selama empat tahun tidak sesuai harapan. Bisa saja sebagian masyarakat sebagai pemilih, memang belum merasakan upaya DPR dalam menyejahterakan rakyat secara faktual. Walaupun dalam tataran retorika politik, wakil rakyat gemar mengusung jargon - jargon keberpihakan kepada rakyat.

Kondisi ini tampaknya berlanjut pada tahun 2011 yang tingkat kepercayaan publik semakin menurun. Hasil jajak pendapat Kompas tentang Citra DPR, hanya 14,6\% yang menyatakan bahwa citra DPR baik, sedangkan 78,2\% menyatakan citra DPR buruk tidak sesuai yang mereka harapkan, dan 7,2\% menyatakan tidak tahu atau tidak menjawab. (Kompas, 11 April 2011)

Lebih memprihatinkan pendapat masyarakat terhadap kinerja DPR yang dinilai semakin memburuk. Padahal dalam berbagai kesempatan, para elite negeri ini mengkritisi agar anggota legislatif lebih berperan dalam menyejahterakan rakyat tanpa perbedaan sosial, ekonomi dan politik. Dikemukakan oleh responden bahwa, $72,3 \%$ anggota DPR tidak peduli terhadap kritik mencapai $72,3 \%$, yang menyatakan DPR peduli terhadap kritik 22,9\%, dan tidak Menjawab sebesar 4,8\% (Kompas, 2011).

Selanjutnya polling paling akhir pada bulan Maret 2013 yang dilakukan Surat Kabar Harian Kompas, menyangkut kualitas wakil rakyat dikaitkan dengan mekanisme penjaringan caleg, juga menunjukkan hasil yang tidak jauh berbeda. Tabel dibawah ini menunjukkan pendapat responden terhadap kualitas wakil rakyat yang akan bersaing memperebutkan kursi anggota legislatif pada Pemilu tahun 2014.

Tabel 2 Polling Kompas tentang pendapat responden mengenai kualitas wakil rakyat dalam Pemilu 2014

\begin{tabular}{cc}
\hline Karakter wakil Rakyat & Jumlah (\%) \\
\hline $\begin{array}{c}\text { Wakil rakyat yang membela } \\
\text { kepentingan sendiri }\end{array}$ & $39,6 \%$ \\
\hline $\begin{array}{c}\text { Wakil rakyat yang aspiratif } \\
\text { pada kepentingan rakyat }\end{array}$ & $29,1 \%$ \\
\hline $\begin{array}{c}\text { Wakil rakyat yang hanya } \\
\text { membela kepentingan partai }\end{array}$ & $26,2 \%$ \\
\hline Tidak Memberikan Jawaban & $1,2 \%$ \\
\hline
\end{tabular}

Sumber : Kompas, 25 Maret 2013.
Mencermati gambaran tersebut, kalau kita ambil dari segi positifnya, maka harapan untuk memperoleh wakil rakyat yang peduli terhadap aspirasi rakyat tetap ada. Walaupun jumlahnya terlampau kecil dibandingkan masyarakat yang mengungkapkan suara sumbang terhadap kualitas wakil rakyat. Namun ternyata dalam perkembangannya, sampai menjelang Pemilihan Umum DPR/DPRD, ternyata kinerja parpol masih tidak memuaskan rakyat. Harian Kompas dalam topik "Rapor Merah Kinerja Parpol" menunjukkan bahwa 69,20 persen responden menayatakan tidak puas terhadap kinerja parpol, 20,10 persen menyatakan puas, sedangkan 10,70 persen tidak menjawab. (Kompas, 23 Desember 2013).

Dalam Diskusi Indonesia Satu "Quo Vadis" DPR Bersih dan Prorakyat (Kompas, 2 Januari 2014) memperlihatkan hal yang sama. Jajak Pendapat Kompas sejak tahun 2007 hingga 2010 menunjukkan, 54,7 persen hingga 65,9 persen responden menilai kinerja DPR buruk. Demikian juga Jajak pendapat Kompas awal Maret 2013 juga menunjukkan, 58 persen responden menyatakan wakil rakyat saat ini lebih banyak membela kepentingan sendiri dan partai masing - masing daripadankepentingan rakyat dan bangsa.

Oleh sebab itu untuk menepis anggapan masyarakat yang cenderung masuk pada kutub negatif, para calon anggota legislatif selayaknya mampu membangun komunikasi politik dengan rakyat, dengan memaparkan berbagai hal yang akan dilakukan jika terpilih sebagai anggota legislatif. Memang terlampau klise, mengingat semua caleg akan menyampaikan hal yang sama. Tetapi dengan dukungan media massa yang independen, maka caleg yang mengingkari janji bisa dengan mudah untuk diberitakan oleh media massa.

Memang tidak mudah mencari caleg yang konsisten dan transparan untuk menunjukkan jati diri sebagai pendukung kompetensinya. Karena itu, demi membangun komunikasi politik yang baik dengan rakyat KPU juga berniat mengumumkan riwayat hidup para caleg sebagaimana yang dikemukanan di media massa. "Komisi Pemilihan Umum mempublikasikan daftar riwayat hidup para calon anggota legislatif DPR. Publikasi riwayat hidup caleg diharapkan memudahkan pemilih menilai calon wakilnya di parlemen. Namun ada beberapa 
caleg yang menolak riwayat hidupnya dipublikasikan. Untuk caleg-caleg ini, KPU akan memberi tanda dan masyarakat dapat menilai sendiri” (Kompas, 8 Juni 2013).

Dengan semakin terbukanya informasi dan komunikasi, maka anggota legislatif diharapkan mampu mengelola komunikasi dengan rakyat secara baik sesuai dengan etika komunikasi. Terlebih lagi salah satu syarat Caleg legislatif seperti tercantum dalam UU No.8/2012 antara lain adalah cakap dalam berbicara, membaca, dan menulis dalam bahasa Indonesia. Kemampuan berkomunikasi bagi calon anggota legislatif berguna dalam melakukan komunikasi politik dihadapak khalayak seperti halnya kampanye.

Kampanye Pemilu yang merupakan bagian dari pendidikan politik masyarakat dan dilaksanakan secara bertanggung jawab harus dimanfaatkan sebaik mungkin oleh para caleg. Pola pengorganisasian pesan yang baik berpijak kepada pengertian komunikasi yaitu proses penyampaian pesan dari komunikator kepada komunikan dengan tujuan membangun pemahaman makna bersama. Untuk mencapai pemahaman bersama, caleg harus mengetahui apa karakteristik masyarakat dan kehendak serta kebutuhan rakyat secara faktual.

Merujuk kepada Nimmo (2007: 2011), "keputusan pemberi suara akan bergantung kepada karakter sosial dan demografi, citra diri kandidat dan isu politik yang dikemukakan'. Pemberi suara sendiri ada yang rasional memperhitungkan secara tepat keuntungan yang diperoleh jika dia memilih kandidat. Pemberi suara reaktif yang cenderung melihat karakteristik berlawanan tidak akan dipilih. Pemberi suara responsif yang memberikan suaranya sebagai bentuk kesetiaan terhadap partai politik tetyapi untuk jangka pendek. Sedangkan pemberi suara aktif adalah mereka yang kritis menganalisis profil, kampanye yang diusung dan track record caleg. Namun secara umum, pemberi suara dalam pemilu, akan mengkaitkan dengan citra partai, citra kandidat dan isu yang diusung

Hasil survei Reform Institute yang banyak dipublikasikan media pada awal Juli 2008, dalam menentukan pilihan caleg, pilihan pemberi suara didasarkan pada (1) Kesamaan Agama: 33,76\%, (2) Anjuran Tokoh sebanyak 28,51\%, (3) Partai Pendukung: $28,13 \%$. Selain itu, dihubungkan dengan sipil atau militer, sekitar
$60,12 \%$ tidak mempersoalkan militer atau sipil. Sedangkan dihubungkan dengan masalah etnik, 65,48 responden tidak mempersoalkan Jawa ataupun Non Jawa. Komposisi jawaban responden tersebut menunjukkan kebebasan berekspresi dalam pemilihan umum yang berjalan kearah demokratisasi bernegara.

Sedangkan dalam survei Kompas (2 Februari 2009), faktor yang mempengaruhi pilihan caleg tahun 2009 adalah sebagai berkut:

Tabel 3 Polling Kompas tentang pendapat responden mengenai faktor yang mempengaruhi pilihan caleg 2009

\begin{tabular}{ccc}
\hline Karakter & Mempengaruhi & $\begin{array}{c}\text { Tdk } \\
\text { mempengaruhi }\end{array}$ \\
\hline $\begin{array}{c}\text { Sama Jenis } \\
\text { Kelamin }\end{array}$ & $15,7 \%$ & $84,3 \%$ \\
\hline $\begin{array}{c}\text { Sama } \\
\text { Agama }\end{array}$ & $38,9 \%$ & $61,1 \%$ \\
\hline $\begin{array}{c}\text { Sama } \\
\text { Daerah }\end{array}$ & $12,8 \%$ & $87,2 \%$ \\
\hline $\begin{array}{c}\text { Sama } \\
\text { Etnis }\end{array}$ & $17,3 \%$ & $82,7 \%$ \\
\hline $\begin{array}{c}\text { Artis/ } \\
\text { Selebriti }\end{array}$ & $5,9 \%$ & $94,1 \%$ \\
\hline Sumber: Kompas, 2 Februari 2009
\end{tabular}

Sumber : Kompas, 2 Februari 2009

Dari tabel tersebut, dapat disimpulkan bahwa masyarakat dalam menentukan pilihan, tidak tersekat dalam semangat etnosentrisme atau kedaerahan, semangat sektarian yang lebih mengedepankan nilai - nilai yang berlaku di lingkungannya dan merekapun ternyata tidak peduli terhadap posisi caleg yang menyandang status selebriti. Dengan demikian, caleg yang akan bersaing dalam Pemilu 2014, dapat mempersiapkana diri untuk mengatur model kampanye dengan mengorganisasikan pesan yang berfokus kepada kepentingan khalayak.

Namun dalam koridor pemilu yang bebas dan rahasia serta bebas dari tekanan pihak manapun, sulit untuk mempengaruhi masyarakat untuk konsisten memilih caleg sampai ke bilik suara. Dinamika politik yang sangat kompleks, dalam arti bukan sebatas urusan janji kampanye, ideologi partai, orientasi kerja para caleg, tetapi pemilu juga dihadapkan pada persoalan krusial dalam jerat politik uang yang semakin tampak menggejala dalam kontestasi politik lokal maupun nasional. 
Dalam skeptisme politik dan ketidakpercayaan terhadap elite partai, maka pilihan praktis dalam jerat politik uang menjadi biasa. Kendati demikian, demi memberikan pelajaran politik yang baik kepada rakyat, maka caleg yang memiliki kapasitas sebagai legislator, harus manjalankan komunikasi politik dengan khalayak agar krediblitasnya terjaga dan pemilih tidak menghiraukan godaan politik uang.

\section{SIMPULAN}

Komunikator politik tidak dapat melepaskan diri dari kemampuan dalam mengorganisasikan pesan kepada khalayak yang menuntut demokratisasi dalam bernegara, kesejahteraan dan keadilan. Esensi komunikasi politik, khususnya yang berhubungan dengan pengaturan dan penyebaran pesan politik demi mempengaruhi khalayak ataupun calon pemilih.

Upaya mempengaruhi partisipasi masyarakat dalam pemilihan umum, bukan pekerjaan mudah, mengingat respon khalayak berbeda - beda tergantung dari karakter yang melekat. Pengaturan pesan dalam komunikasi politik yang menyentuh kebutuhan masyarakat secara mendasar akan meningkatkan partisipasi masyarakat dalam kegiatan politik, khususnya pemilu dan membangun kredibilitas komunikator politik dengan partai politiknya secara positif.

Anggota legislatif yang berpihak kepada rakyat merupakan harapan masyarakat dalam memberikan suaranya dalam pemilu legislatif. Elite parpol dalam jargon demokratisasi bernegara, justru seringkali terperangkap dalam jerat kebebasan memperjuangkan kepentingan kelompok dan memicu kritik kepada anggota legislatif.

Sedangkan saran yang peneliti ajukan berdasarkan hasil penelitian ini antara lain adalah:

Komunikator politik seyogianya mempunyai kemampuan berkomunikasi di depan publik, menyampaikan pesan secara jujur, memahami media komunikasi yang dimanfaatkan ketika bicara dengan khalayak, mengetahui khalayak yang menjadi sasasaran dalam komunikasi publik demi untuk mencapai tujuan yang telah ditetapkan.

Dalam rangka mempengaruhi khalayak supaya partisipasi dalam pemilihan umum, para komunikator politik harus menyampaikan pesan yang menyentuh kebutuhan masyarakat dalam pencapaian keadilan dan kesejahteraan yang benar - benar dirasakan manfaatnya.

Para komunikator politik, aktivis politik maupun anggota legislatif harus memiliki keberpihakan kepada rakyat untuk memperjuangkan kepentingan seluruh rakyat tanpa diferensi nilai, sikap dan kepercayaan dalam kehidupan bernegara.

\section{DAFTAR PUSTAKA}

Baran, S. J. (2012). Pengantar komunikasi massa: melek media dan budaya. Jakarta: Penerbit Erlangga

Biagi, S. (2005). Media impact: an introduction to mass media. Seventh Edition, United States: Thomson - Wadsworth.

Bower, J. W. \& James J. B. (1982). Issues in communication theory: a metatheoritical analysis, communication yearbook 5. Sage Publication.

Budiardjo, M. (2004). Demokrasi di Indonesia: demokrasi parlementer dan demokrasi pancasila. Jakarta: Gramedia.

Haryanto, I. (2010). Media di bawah dominasi modal: ancaman terhadap hak atas informasi" dalam azasi. Edisi Maret - April 2010

Henessy, B. (1990). Pendapat umum, terjemahan Airuddin Nasution, Jakarta: Erlangga.

Klepper, O. (1980). Advertising procedure. New Jersey: Prentice Hall Inc

Kominfo. (2012). Komunikasi politik elite pemilu 2014. Diakses dari https://www.google. $\mathrm{m} / \# \mathrm{q}=$ komunikasi + politik + elite + pemilu+2014.

Kompas. (2007). Citra DPR. Harian Kompas, 27 Agustus 2007

Kompas. (2009). Perolehan suara dalam Pemilu. Harian Kompas, 10 Mei 2009

Kompas. (2009). Faktor yang mempengaruhi pilihan caleg. 2 Februari 2009

Kompas. (2011). Kinerja DPR kini makin buruk saja. Harian Kompas. 11 April 2011

Kompas. (2013). Kualitas wakil rakyat buruk. Harian Kompas 25 Maret 2013

Kompas. (2013). Pemilu legislatif: daftar riwayat hidup caleg dipublikasikan" Rubrik Politik dan Hukum, Harian Kompas. Sabtu, 8 Juni 2013

Kompas. (2013). Rapor merah kinerja parpol, Harian Kompas. 23 Desember 2013

Kompas. (2014). Diskusi Indonesia satu "Quo 
Vadis" DPR bersih dan prorakyat. Harian Kompas 2 Januari 2014

Lull, James. (1999). Media: komunikasi dan kebudayan. Jakarta: Yayasan Obor.

Moleong, L. J. (2005). Metodologi penelitian kualitatif. Bandung: Remaja Rosda Karya

Nimmo, D. (2007). Political communication and public opinion in America,atau komunikasi politik: komunikator, pesan dan media, Cetakan kedua, terjemahan Tjun Surjaman, Bandung: Remaja Rosda Karya.

Pikiran Rakyat. (2013). Diakses dari http:// www.pikiran-rakyat.com/node/262006.

Republika. (2013). Surya Paloh bangun komunikasi dengan Megawati. Diakses dari http://www.republika.co.id/berita/nasional/ politik/13/09/17/mt9gu5-surya-paloh-bangun-komunikasi-politik-dengan-megawati

Rush, M. \& Althoff, P. (1997). An Introduction to Political Sociology, atau Pengantar Sosiologi Politik, terj. Kartini Kartono, Jkt: Rajawali Pers.

Setiawan, B. (1990). Komunikasi politik dan ketahanan nasional, percikan pemikiran $\mathrm{Fi}$ - sipol UGM tentang pembangunan. Cetakan Kedua. Yogyakarta: Aditya Media.

Suhardi. (2013). Gerindra kritik warga negara yang golput. Diakses 16 Desember 2013 dari $\mathrm{http} / /$ nasional.kompas.com/read/2013/11/01/ 2236319/Gerindra.Kritik. Warga.Negara. yang.Golput.

Susanto, E. H. (2012). Iklan politik dan kegagalan partai politik" dalam media dan komunikasi politik (ed. Heri Budianto). Jakarta: Litera

Undang - Undang Dasar 1945. Sejarah UUD 1945 sejak pembentukan hingga amandemen pada zaman reformasi. Jakarta: Visi Media.

Undang - Undang Republik Indonesia Nomor 8 Tahun 2012 tentang Pemilihan Umum Anggota Dewan Perwakilan Rakyat, Dewan Perwakilan Daerah, Dan Dewan Perwakilan Rakyat Daerah

West, R. \& Turner, L. H. (2008). Pengantar teori komunikasi: analisis dan aplikasi, atau introducing communication theory: analysis and application. Jakarta: Salemba Humanika. 